が。近年発電所のフライアッシュをポンプで払跡に圧送し 充てんする方法が常磐炭鉱ほか $2 ， 3$ の炭鉱で採用され， 廃物処理を兼祇た完全充てんによる保安上の利点が注目さ れる。

\section{7. 特殊採炭ほか}

採炭の機械化に当つて問題が残されているのは厚層と急傾 斜の採掘である。

緩傾斜の厚層では通常スライシング採炭が行なわれるが， その場合に上段の払では下段払のための人工天井材を敷込 まなければならないので，自走支保を使うことがむずかし

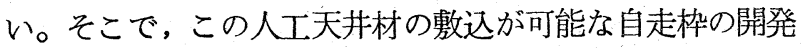
研究を各所で行なつているが，いまのところまだ決定的な ものはできていない。またこの厚層を一段で払うための厚 層用自走枠は一時三池炭鉱で実用化されたが，現在は使わ れていない。しかしこのような厚層用自走枠に対する要 求は各所にみられる。

次に急傾斜層の機械化については，そのための自走支保 や採炭機の䀢発に多くの努力が払われたにもかかわらず， 一部の自走支保を除いては実用に至らなかつた。これは急 傾斜層が不安定で片盤を長くとれない上に，保安上必要な 充てん作業によつて切羽進行が制約され，重装備の機械化 は経済的に引合わない。したがつて急傾斜層の採掘は依然 としてピックと発破に依存し，また支保の鉄化もその重量 と充てん作業との関連のために遅れている。このままでは 生産性の面だけでなく，労働力の面からも急傾斜の採掘は 行詰まることになろう。ただ条件さえ許すならば次に述べ る水力採炭か唯一の活路になるものとみられる。

わが国に打ける水力採炭は 35 年以来政府の石炭技術振 興費補助金によつて行なわれた一連の炭鉱水力化に関する 試験によつて技術が開発され，実用化された。そして実施 炭鉱は 40 年に 12 に，また出炭は 42 年に 10.7 万 $\mathrm{t} /$ 月 に達したが,これらをピークに減少している。これは水力 採炭実施炭鉱中に閉山が相次いだためであるが，一方能率 は年とともに上昇し 45 年には $1.4 \mathrm{t} /$ 日/人になつた。 この経過を第 5 図に示す。更にこの図にみられるように水 力採炭実施炭鉱の歩留りが非常に悪いことからみても, こ
の採炭能率が高度機械化切羽の能率に十分匹敵するもので あることがかかる。この水力採炭が期待に反して全出炭の 2〜3\%程度にしか普及しなかつた理由には。濁水処理； 坑道維持更には新規投資なぞの問題点があげられるが, 新 鉱開発特にカナダの例にみられるような急傾斜厚層の場合 には，ぜひとも考慮すべき採炭法であろう。

最後に露天掘が近年その割合を増したがこれはパワーシ ヨベルを初好とする土木機械の進歩。特にその強力化と高 性能化によるもので。炭層厚の 5 倍以上の表土をはいでも 採算があるといわれ，貝島炭鉱の例では表土はぎ取作業の 人員を含めても $150 \mathrm{t} /$ 人月以上 $200 \mathrm{t} /$ 人月に近い高能 率をあげている。

\section{8. むすび}

以上わが国における採炭の現状，特にその機械化につい て述べたが，今後炭鉱の切羽条件はますます悪化し，労慟 力不足に加光て老龄化して行く中で，しかも深刻化するエ ネルギー事情に対処しなければならないことを考光ると， その作業の機㳚化による合理化。省力化は炭鉱技術者に課 せられる必然的な要求である。

な扔次に発表される報文はわが国における機械化採炭の 代表的な例である。すなわちホーベル採炭で実績をあげ， 更にドラムカッタと自走支保による完全機械化にも成功し， それに移行しつつある棍内炭鉱の例, 極めて薄い炭層の悪 条件にもかかわらずホーベルと自走支保による完全機戌化 採炭に成功した福島炭鉱の例, レンジングドラムカッタの 導入で高能率をあげている池島炭鉱の例，わが国で初めて シールド型自走枠を導入し，いわゆる画期的な S D 切羽を 完成した釧路炭鉱の例, 更にシールドとチョックを組合わ せた型の強力自走枠で記録的な成績をあげた三池四山鉱の 例, チョック型の枠で中傾斜の自走支保化に成功した高島 二子鉱の例, 最後に採掘の困難なガスの多い急傾斜炭層に 水力採炭を採用して成功した砂川炭鉱の例が報告される。 もちろん,これ以外にも技術的に価値ある業績をあげた炭 鉱恀多い行れども，中でもこれらは。わが国の炭鉱におけ る採炭技術の枠として長く記録に残されるべきものであろ う。

\title{
幌内炭鉱のホーベル採炭について
}

On the Coal Getting by Coal Plough(Hobel) at Horonai Colliery

$$
\begin{aligned}
& \text { 山 本 和 } \text { 男 }^{1} \\
& \text { Kazuo YAMAMOTO }
\end{aligned}
$$

1.はじめに

1. 正会員 北海道炭砇株式会社帽内炭矿 生産課長
当鉱では昭和 36 年にウンバウホーベルを導入して以来, 逐次ホーベルを増強し，昭和 37 年から全切羽ホーベル採 炭を実施してきた。しかし飛躍的な能率向上と完全機械化 
口採崖

採炭をめざして，昭和 44 年よりドラムカッタと自走枠を 導入し，その効果をあげている。

しかしながら現在では, なお全切羽の半数をホーベル切 羽が占めており，ホーベル採炭の向上を図らねば, 幌内炭 鉱の発展はあり得ないと考えている。

以下ホーベル採炭の概要を報告するとともに,ドラムカ ッタとの比較にも触れてみたいと思う。

\section{2. 幌内岸鉱の概要}

現在の坑口水準は $+55 \mathrm{~m}$ で, 採掘深度は $-790 \mathrm{~m}$ であ る。人員の入昇坑およびズリ・材料の搬出入は幌内立坑に より，また揚炭はベルト斜坑によつており，現在の出炭は $4,600 \mathrm{t} /$ 日 程度である。

地質状態は白亜紀層を基盤に古第三紀石狩層群の幾春別 層があり，その上部に沅内層が堆積している。幾春別層は厚 さ約 $300 \mathrm{~m}$ で 10 数枚の炭層があるが, 稼行対象は第 1 表 の通りで7枚である。

\section{3. 採炭機械の導入・仕様の概要}

\section{$3 \cdot 1$ ホーベルの導入}

昭和 36 年にウンバウホーベルを導入し，その後標準型 から硬炭型に変えて切削能力の増強を図つたが，昭和 39 年からライスハーケンホーベルを導入し今日に至つている。 なお昭和 42 年にグライトホーベルを使用したが，下艋調 整がさずかしく期待した効果は上らなかつた。

現在ホーベルの保有台数は 9 台で，その内訳はウンバウ 標準型 2 台, 同硬炭用 2 台, ライスハーヶンD型 2 台, 同 $\mathrm{E}$ 型 1 台, 同フッケパック 1 台, およびグライト 1台とな つている。6 月現在稼働中のものは, ウンバゥ硬炭用 1 台, ライスハーケンD型 2 台の合計 3 台となつている。

$3 \cdot 2$ シフ夕

初めはエアシフタ（ストローク $700 \mathrm{~mm}$ ，押付力 $1.1 \mathrm{t}$ ) を使用したが，ライスハーケンを導入してから，1方当り の進行増が要求され, 41 年から油圧シフタ（ストローク $750 \mathrm{~mm}$, 押付力 $1 \sim 3 \mathrm{t}$ ) を使用している。油压シフタ は推力が一定であり，押付力を調整できることが有利であ

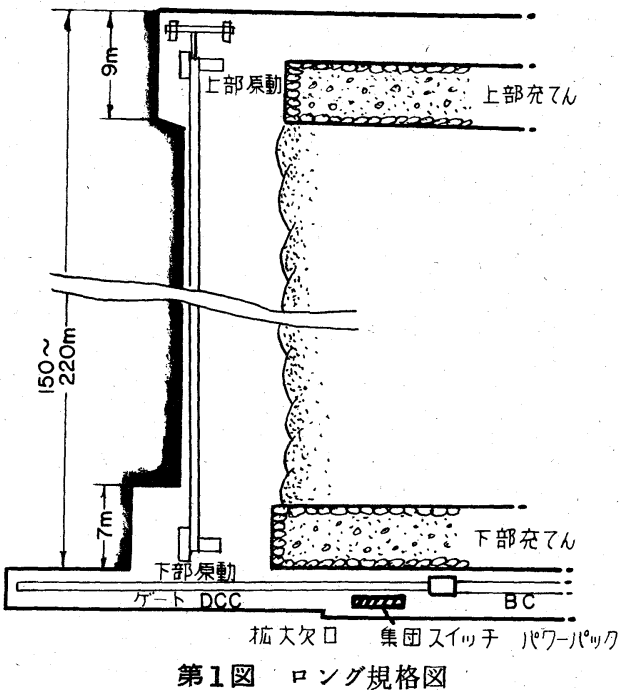

る。

$3 \cdot 3$ 鉄柱・カッペ

ホーベル岈羽では三池フェロ鉄柱を使用しているが, 一 部薄層でダウテイ油圧鉄柱を使用している。な拉ドラムカ ッタ切羽は自走枠を 2 切羽て使用している。

カッペは大同の $1.4 \mathrm{~m}$ ピンタイプ強力型 (本体強度 10 $\mathrm{mm}$ 撓みで $56 \mathrm{t}$, ゲレンク強度 $10 \mathrm{~mm}$ 撓みで $14 \mathrm{t}$, 上 下調節範囲は $+4.5^{\circ} \sim-9^{\circ}$, 左右調節範囲は土 $3^{\circ}$ )で ある。

\section{4. 採炭切羽の設定}

\section{$4 \cdot 1$ 切羽の設定}

片盤坑道を垂直 $70 \mathrm{~m}$ ごとに設けて, 炭層傾斜は $20^{\circ}$ 前後, 面長は $150 \sim 220 \mathrm{~m}$ となつている。採炭方式は総 ばらし長壁式前進払である。な㧍自走枠切羽は中切坑道を 設けて, 面長 $100 \mathrm{~m}$ 前後にして後退式払にすることが多い。

\section{$4 \cdot 2$ ロング規格}

切羽は真傾斜として。千鳥式 $3-2$ 列柱方式であるが 3 - 3 列柱にする場合もある。枠間は $0.60 \sim 0.70 \mathrm{~m}$ である。 上部ステーブルはロング面より約 $2.8 \mathrm{~m}$ 先行させて長さ

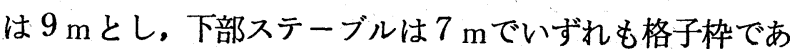
る。代表的なホーベル切羽の規格を第 1 図に示す。
第1表 稼行炭層状況

\begin{tabular}{|c|c|c|c|c|c|c|c|}
\hline & & 稼行丈 (m) & $\begin{array}{l}\text { フライヤ } \\
\text { ビリティ }\end{array}$ & $\begin{array}{l}\text { 炭理の } \\
\text { 状 況 }\end{array}$ & 天 盤 & 下 盤 & 備 \\
\hline 中 & $\begin{array}{lr}5 & \text { 層 } \\
4 & \text { 上層 } \\
4 & \text { 層 } \\
3 & \text { 層 }\end{array}$ & $\begin{array}{l}\text { 1. } 38 \sim 2.20 \\
\text { 1. } 70 \sim 2.14 \\
1.70 \sim 2.30 \\
\text { 2. } 10 \sim 2.30\end{array}$ & $\begin{array}{c}20 \sim 22 \\
21 \\
15 \sim 17 \\
24 \sim 26\end{array}$ & $\begin{array}{ll}\text { 良 } & \text { 好 } \\
\text { 普 } & \text { 通 } \\
\text { 維 } & \text { 密 } \\
\text { 良 } & \text { 好 }\end{array}$ & $\begin{array}{l}\text { S.S 硬 } \\
\text { S.S 硬 } \\
\text { Sh 脆弱 } \\
\text { Sh 硬 }\end{array}$ & $\begin{array}{l}\text { Sh 脆弱 } \\
\text { Sh 普通 } \\
\text { Sh 硬 } \\
\text { Sh 硬 }\end{array}$ & 西部区域のみ \\
\hline 層 & $\begin{array}{l}5 \text { 上層 } \\
3 \text { 覻 } \\
\text { 前 顱 }\end{array}$ & $\begin{array}{l}1.20 \sim 1.70 \\
1.00 \sim 1.20 \\
0.90 \sim 1.10 \\
1.00 \sim 1.40\end{array}$ & $\begin{array}{c}19 \\
24 \sim 26 \\
19 \sim 21 \\
25 \sim 27\end{array}$ & $\begin{array}{l}\text { 普 通 } \\
\text { 良 好 } \\
\text { 普 通 } \\
\text { 良 好 }\end{array}$ & $\begin{array}{ll}\text { S.S 硬 } \\
\text { Sh 硬 } \\
\text { Sh 硬 } \\
\text { Sh 硬 }\end{array}$ & $\begin{array}{l}\mathrm{Sh} \\
\mathrm{Sh} \text { 脆弱 } \\
\mathrm{Sh} \text { 硬 } \\
\mathrm{Sh}\end{array}$ & \\
\hline
\end{tabular}

\section{5. 採炭作業工程}

\section{1 採炭作業工程}

ホーベルの切削は，肩側より分割切 削を行なつて順次深側に移行する。運 行部の作業人員は固定番割方式で, 回 収から作業を開始して，ホーベル切削 後カッぺ延長・立柱を行なう。したが つて深側は手待ち時間が多いため時差 入坑をしている。立柱終了後必要があ れば, 次の切削のためにさく孔・発破 を行なう。これで1サイクルが終了し， 
2 サイクルの場合はこれをくり返すわけである。

\section{$5 \cdot 2$ 切羽内作業人員}

切羽作業人員は第 2 表の通りであるが, 運行部支保人員 は実績から各要素作業速度と切さく能力の関係から検討し てきめる。一般に 1 組 ( 2 人) の持幅は $0.7 \mathrm{~m}$ 進行に換算 して, 中層は $40 \mathrm{~m}$, 薄層は $50 \mathrm{~m}$ 強である。下盤調整の人 員は，下盤調整および吊炭のための発破作業人員である。

この外，表にはのせていないが，3番方で注水を行なつ ている。また注水効果のない切羽では切さく時散水を実施 している。

\section{6. ホーベルの切削状況}

\section{6・1 ホーベル 切羽の実績}

第 3 表は 3 月の実績を示している。ホーベル切羽の実績 は, 自走枠とドラムカッタの組合せに比較して, 能率は低 い。ただホーベル切羽は薄層または上下盤の不良な䇢所を 採淈していることも，能率の低い原因の一つである。

\section{6 - 2 ホーベル稼㗢率の向上}

稼働率は第 3 表のごとく $50.8 〜 56.2 \%$ を示して扔り， 若干向上の傾向はみられるが, やはり低いといわざるを得 ない。この原因として大塊発生による炭割時間, 払落口の 炭つかえ，および運般系統の故障などがある。しかし停止 時間の $40 \sim 50 \%$ は炭割時間である。この対策として高 圧注水による炭壁の軟化を図つているが，切羽条件によっ て不可能な場合があるので，さく孔技術の向上により発破 効果を良くし，極力大塊の発生を防止している。

\section{6 ・3 ホーベルの切削深さ}

切羽能率の向上は，稼働率の向上と切削深さを増すこと である。切削深さを増すためには, シフタ管理を良くする 第2表 ロング内作業人員/方

\begin{tabular}{|c|c|c|c|c|c|c|c|c|c|c|c|}
\hline \multirow{3}{*}{$\begin{array}{l}\text { 層 } \\
\text { 別 }\end{array}$} & \multirow{3}{*}{$\begin{array}{c}\text { ホ } \\
1 \\
\text { ふ } \\
\text { ハ } \\
\text { 監 } \\
\text { 視 }\end{array}$} & \multirow{3}{*}{$\begin{array}{l}\text { シ } \\
\text { フ } \\
\text { タ } \\
\text { 管 } \\
\text { 理 }\end{array}$} & \multirow{3}{*}{ 割 } & \multirow{3}{*}{$\begin{array}{c}\text { 炭 } \\
\text { は } \\
\text { ね }\end{array}$} & \multirow{3}{*}{ 運 } & \multirow{3}{*}{$\begin{array}{l}\text { 面 } \\
\text { 支 } \\
\text { 保 }\end{array}$} & \multicolumn{3}{|c|}{ ステーブル（1.4 m進行 $)$} & \multirow{3}{*}{$\begin{array}{l}\text { 下 } \\
\text { 盤 } \\
\text { 調 } \\
\text { 整 }\end{array}$} & \multirow{3}{*}{$\begin{array}{l}\text { 充 } \tau ん \\
(1.4 \mathrm{~m} \text { 進行 })\end{array}$} \\
\hline & & & & & & & \multicolumn{2}{|c|}{ 上部 $(9 \mathrm{~m})$} & \multirow{2}{*}{$\begin{array}{l}\text { 下 } \text { 部 } \\
(7 \mathrm{~m})\end{array}$} & & \\
\hline & & & & & & & $\begin{array}{l}\text { タックル } \\
\text { ブロック }\end{array}$ & $\begin{array}{l}\text { アンカ } \\
\text { レージ }\end{array}$ & & & \\
\hline 層 & & \multirow{2}{*}{1} & $1 \widetilde{2}$ & \multirow{2}{*}{1} & \multirow{2}{*}{1} & \multirow{2}{*}{$\begin{array}{l}\text { 口 } \\
\text { 兑 } \\
\text { 毎 } \\
\text { 算 } \\
\text { 尊 }\end{array}$} & 6 & 5 & \multirow{2}{*}{2} & \multirow{2}{*}{1} & 2 \\
\hline 層 & & & 1 & & & & 5 & 4 & & & $1 \sim 2$ \\
\hline
\end{tabular}

とともに，下艋調整は機を失しないよう実施し，ホーベル ビットの点検および定期的な交換をするようにしている。

現在までの使用経験によれば, 薄層において, ウンバウ ホーベルを 2 台使用することにより 1 台の場合に比して 150 \%増, ライスハーケンでは $\mathrm{D}$ 型から $\mathrm{E}$ 型に切替えるこ とにより $143 \%$ 増の結果が得られている。また水压鉄柱使 用により $112 \sim 136 \%$ の切削梁さ向上がみられた。

\section{7. ホーベル切羽の管理}

ホーベル訒羽は払の直線化と, 日常の保安点検を確実に 実施することにより故障は少なくなる。点検要領および整 備基準をつくり，機械の管理を徹底して実施している。そ の主なものは次の通りである。

7・1 ライスハーケンホーベル

(1) チェーンアタッチメントは厚さ $19 \mathrm{~mm}$ 以下はとり かえる。

(2) チェーン付 I ボルトは 2 カ月ごとにとりかえる。

(3) チェーンガイドは内弦寸法 $228 \mathrm{~mm}$ でとりかえる。

(4) 蝶番ピンは定期的にとりかえる。

$7 \cdot 2$ ウンバウホーベル

(1) ガイドチューブは定期的に再締めする。

(2) ガイドチューブの変形したものはとりかえる。

\section{7・3 シフ夕管理}

シフタ推力はコンベヤの前進，切削深さおよび下盤の調 整を左右するものなので, 次の点に留意している。

（1）シフタの間隔は $4.5 \mathrm{~m}$ としトラフに直角に布設する。

（2）常に下盤の状態に留意し, ジョイニシグピースの 4 つの孔を有効に利用して調整する。

（3）油圧シフタはパワーパックの油量に常時注意し，ス トレーナの掃除は定期的に行なう。

(4) 油圧シフタはホースの破損・洩油に注意 し，延長切詰時の高圧・低圧側の連結誤りがな いよう点検する。

\section{7・4 払の管理}

（1）払のわん曲・下盤の起伏は、コンベヤの 破損・コンベヤのチェーン切れなどの事故を起 すばかりでなく，ホーベルの切削効率を減少さ せるので，切羽を直線に保ち，下盤調整により 起伏をなくするように努める。

第3表 3 月分切羽実績表

\begin{tabular}{|c|c|c|c|c|c|c|c|c|c|c|c|c|}
\hline & \multicolumn{2}{|c|}{ 使 用 機 器 } & \multicolumn{2}{|c|}{ 切 } & \multicolumn{2}{|c|}{ 条件 } & \multirow{2}{*}{$\begin{array}{l}\text { 原 } \\
\text { 炭 } \\
\text { 能 } \\
\mathrm{t} / \text { 率 }\end{array}$} & \multicolumn{2}{|c|}{$\mathrm{t}$ 当り資材 } & \multirow{2}{*}{$\begin{array}{l}\text { 稼 } \\
\text { 㗢 }\end{array}$} & \multirow{2}{*}{ 切 削(截) } \\
\hline & & 採 炭 機 & 支 保 & 傾斜 ${ }^{\circ}$ & 面長m & 山丈 $m$ & 炭丈 m & & 爆薬 $\mathrm{g}$ & 坑木 $\mathrm{m}^{8}$ & & \\
\hline \begin{tabular}{l|l} 
小川 \\
1 \\
\end{tabular} & $\mid \begin{array}{l}\text { 西部四片前䁲 } \\
\text { 布引四片片三三曙 }\end{array}$ & 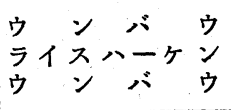 & $\begin{array}{l}\text { フェロ } \\
\text { フェロ } \\
\text { ダウテイ }\end{array}$ & & $\begin{array}{l}198 \\
202 \\
145\end{array}$ & $\begin{array}{l}\text { 1. } 13 \\
\text { 1. } 74 \\
1.06\end{array}$ & & $\begin{array}{r}11.9 \\
17.7 \\
8.6\end{array}$ & $\begin{array}{r}240 \\
163 \\
89\end{array}$ & & $\begin{array}{l}54.3 \\
50.8 \\
56.2\end{array}$ & $\begin{array}{l}7.16 \mathrm{~cm} / \text { 回 } \\
6.21 \mathrm{~N} \\
7.00 \mathrm{~N}\end{array}$ \\
\hline $\begin{array}{l}\text { lis } \\
\text { ラ. } \\
\text { 厶多 }\end{array}$ & 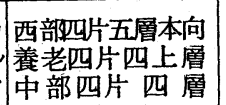 & $\begin{array}{l}\text { ダブルレンジング } \\
\text { ダブルレンジング } \\
\text { シングルレンジング }\end{array}$ & & & $\begin{array}{l}204 \\
105 \\
184\end{array}$ & & & $\begin{array}{l}\text { 16. } 1 \\
\text { 35. } 8 \\
\text { 17. } 6\end{array}$ & $\begin{array}{l}45 \\
40 \\
74\end{array}$ & & $\begin{array}{l}62.8 \\
65.5 \\
68.1\end{array}$ & $\begin{array}{l}2.81 \mathrm{~m} / \text { 分 } \\
2.95 \mathrm{~N} \\
3.00 \mathrm{~N}\end{array}$ \\
\hline
\end{tabular}


第4表出炭および能率比較

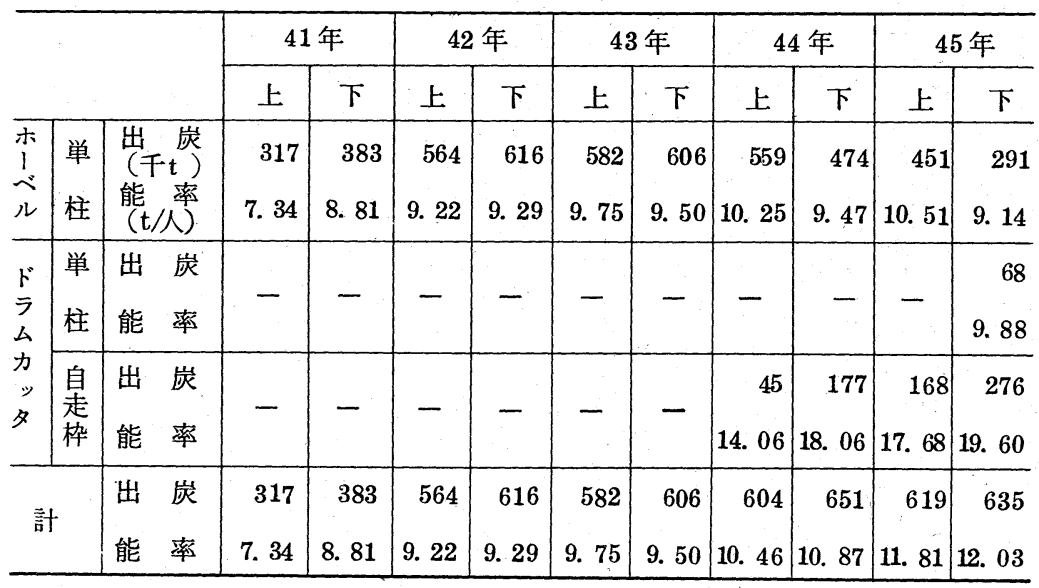

持つものと思われる。

第 4 表はホーベルとドラムカッタの能 率比較である。ホーベルは 42 年より若 干の上昇の兆しは見えるが，ほぼ横ばい であるのに対して,ドラムカッタは漸次 上昇している。出炭の比率も 45 年下期 からは逆転して，ドラムカッタが主 力となつた。特に 46 年 2 月には，自 走枠とドラムカッタの組合せで $52 \mathrm{t} /$ 人の実績がある゙。

\section{9. 結 び}

前述のごとく昭和 36 年にホーベルを 導入以来, 在籍 1 人当り能率を $60 \mathrm{t}$ 以

（2）切削後天盤をゆるめないように直ちにカッぺを延長 し，立柱は天盤の当り付けを充分に行なつて締上げる。

8. ホーベルとカッタとの比較

ホーベル採炭は, 昭和 36 年以来常に新鋭機を導入し， それとともに能率も向上した。これは係員はじめ作業員が， ホーベルの基礎知識を充分マスターしていることを示して いる。したがつて能力出炭に対する実出炭の安全率は非常 に高い。

これに対してドラムカッタ採炭は, 単柱と組合せた場合 ホーベルに近い安全率を示しているが，自走枠との併用で は，使用経験が浅いことにもよるが不安定である。これは カッタは一応使いこなしているが, 自走枠は自然条件に大 きく左右され，特に断層の有無はその成否に致命的影響を
上にした。ただ高性能のホーベルにより切削を早めても， 立柱・回収の速度に限度があり，ホーベルの稼働率を上昇 させることができない。これを解決するために 44 年から 自走枠を導入し，更にダブルレンジングドラムカッタとの 組合せにより，飛踓的な能率向上を図つているが，薄層な らびに上下盤不良の箇所はやはりホーベルに頼らざるを得 ない。

ホーベル岈羽の今後の課題としては, 運行部の人員減少 には限度があるので, 上下ステーブルの人員減を図らねば ならない。現在ドラムカッタ切羽では 1 歩進めて, ノンス で,上部も 8 月から試験的に実施する予定である。これを ホーベル切羽にも適用するため検討中である。 テーブル化を検討中であり，下部ステーブルは既に実施中

\section{中興福島炭鉱におけるホーベル採炭と自走支保}

\section{Coal Plough(Hobel)and Powered Supports at Chuko Fukushima Coal Mine}

\section{杉本 勝 英 ${ }^{1}$ \\ Katsuhide SUGIMOTO}

\section{1. ホーベルの採用より現在までの経緯}

\section{$1 ・ 1$ ホーベル導入のいきさつ}

当鉱の稼行炭層である鍋串二枚層は第 1 図の通りの薄層 でその上，約 $45 \mathrm{~cm}$ の中硬を有し機械化を進めていくには 悪条件の炭層である。昭和 36 年まで 60 円ュールカッタ による採炭を続けてきたが，カッタ採炭では切羽能率 3 $4 \mathrm{t} /$ 人方程度, 1 切羽当りの出炭は 1 万 $\mathrm{t} /$ 月前後で出 炭量および切羽能率の限界に達した。そこで新たな採炭機 械の導入の必要にせまられ，切羽長が $160 \sim 200 \mathrm{~m}$ で薄

1. 正会員 中興鉱業株式会社福島鉱業所 所長
層採炭に適応し十分機械効率が上げられるものという目標 のもとに効果を検討した。特に本炭層の特徴である約 45 $\mathrm{cm}$ の中硬の処理がカッタ採炭の状況よりみて, ボタ処理 充填に作業時間の $30 \%$ を占めており機械化の難点と考え られていたが，福島二尺層に䀡和 36 年より設備したウン バウホーベルの使用実績が出るに及んでカッタ採炭に比べ てホーベルの場合には払が逐次進行するので盤圧により中 硬が破砕され処理も容易であり，上下盤の状況より見て十 分使用できるとの結論を得て, その採用を決定し, 下盤炭 約 $35 \mathrm{~cm}$ の部分を切削積込みするようにした。

\section{$1 ・ 2$ ホーベル機器の概要}

ライスハーケンホーベル仕様 